BIOS : Jurnal Teknologi Informasi dan Rekayasa Komputer

Vol. 2, No. 2, September 2021, hlm. 51 - 59

ISSN: 2722-0850

Laman Jurnal: http://bios.sinergis.org

\title{
Analisis Review Penggunaan Sistem Informasi pada PT Pertamina
}

\author{
Wahid Wachyu Adi Winarto \\ Institut Agama Islam Negeri Pekalongan \\ wahidwachyuadi@iainpekalongan.ac.id
}

\begin{tabular}{|c|c|}
\hline Keywords: & ABSTRACT \\
\hline $\begin{array}{l}\text { Information System, } \\
\text { Management, } \\
\text { Information Technology }\end{array}$ & $\begin{array}{l}\text { The information system is a means of transforming company data which is closely } \\
\text { related to the efficiency of the company in its operational activities. Along with } \\
\text { technological developments, the application of information technology in the company } \\
\text { is an important factor in increasing the value and competitiveness of the company. So } \\
\text { far, there are still many companies that have not implemented information systems as } \\
\text { expected because there is no standard for supervising the use of information } \\
\text { technology within the company. This research tries to find out how the information } \\
\text { system implementation at PT Pertamina. The sample selection is because PT } \\
\text { Pertamina is a state-owned company with large assets. Data analysis using qualitative } \\
\text { analysis using a systematic review approach. The results of this study indicate that PT } \\
\text { Pertamina has implemented an information system in the form of a management } \\
\text { information system properly in the company as a way to achieve company goals so } \\
\text { that efficiency and competitiveness of the company can be achieved. }\end{array}$ \\
\hline
\end{tabular}

\begin{tabular}{ll}
\hline Kata Kunci & ABSTRAK \\
\cline { 2 - 3 } $\begin{array}{l}\text { Sistem Informasi, } \\
\text { Manajemen, }\end{array}$ Teknologi Informasi & $\begin{array}{l}\text { Sistem informasi merupakan sarana transformasi data perusahaan yang erat } \\
\text { hubungannya dengan efisiensi perusahaan dalam kegiatan operasionalnya. Seiring } \\
\text { dengan perkembangan teknologi maka penerapan teknologi informasi dalam } \\
\text { perusahaan merupakan faktor penting guna meningkatkan value dan daya saing } \\
\text { perusahan. Sejauh ini masih banyak perusahaan yang belum menerapkan sistem } \\
\text { informasi sesuai dengan yang diharapkan karena belum ada standardar untuk }\end{array}$ \\
$\begin{array}{l}\text { penggawasan penggunaan teknologi informasi dalam perusahaan. Penelitian ini } \\
\text { mencoba untuk mencari tahu bagaimana implementasi sistem informasi pada PT }\end{array}$ \\
$\begin{array}{l}\text { Pertamina. Pemilihan sampel dikarenakan PT Pertamina merupakan perusahaan } \\
\text { Badan Usaha Milik Negara dengan asset yang sudah besar. Analisis data } \\
\text { menggunakan analisis kualitatif dengan menggunakan pendekatan systematic review. }\end{array}$ \\
$\begin{array}{l}\text { Hasil penelitian ini menunjukkan bahwa PT Pertamina sudah menerapkan sistem } \\
\text { informasi berupa sistem informasi manajemen dengan baik pada perusahaan sebagai } \\
\text { salah satu cara untuk mencapai tujuan perusahaan sehingga tercapai efisiensi dan daya } \\
\text { saing perusahaan. }\end{array}$
\end{tabular}

\section{Korespondensi Penulis:}

Wahid Wachyu Adi Winarto, Institut Agama Islam Negeri Pekalongan,

Pekalongan, Indonesia

Email: wahidwachyuadi@iainpekalongan.ac.id

\section{PENDAHULUAN}

Perkembangan ilmu pengetahuan dan teknologi informasi yang semakin pesat saat ini, membuat setiap perusahaan yang bergerak di bidang perdagangan maupun jasa harus bersaing dengan perusahaan lain agar dapat tetap eksis, berkembang, dan mampu memenangkan daya saing. Informasi merupakan salah satu sumber daya utama yang dapat menunjang keberhasilan suatu perusahaan. Informasi yang akurat, tepat waktu, relevan, dan lengkap dapat memberikan dukungan dalam pengambilan keputusan yang pada akhirnya dapat meningkatkan kinerja dan pertumbuhan perusahaan [1].

Perubahan penggunaan sistem informasi konvensional yang lebih manual kepada sistem informasi yang otomatis di dalam perusahaan memiliki kecenderungannya akan banyak menemui kendala [2]. Contoh salah satu 
kendala adalah karyawan sebagai penggunanya (end users) kurang mampu beradaptasi dalam menjalankan fungsi sistem informasi tersebut yang disebabkan mereka sudah lama menggunakan sistem secara manual. Untuk mengatasi permasalahan ini, biasanya cara yang dilakukan oleh perusahaan yaitu melakukan pelatihan (training) kepada para karyawannya dengan cara memakai jasa pihak lain atau vendor teknologi informasi (TI) yang sudah berpengalaman di bidangnya.

Ada beberapa cara lainnya, seperti mengadaptasi salah satu dari empat strategi atau model konversi sistem operasi, baik strategi konversi langsung, paralel, pilot, maupun dengan strategi bertahap [3]. Konversi sistem adalah salah satu aspek yang menentukan keberhasilan dalam penerapan sistem informasi yang baru. Pada tahapan konversi ini, aspek non-teknis meliputi pendekatan, metode, strategi manajerial terkait sistem kerja dan organisasi pengguna menjadi perhatian para pengembang di samping aspek teknis pengembangan sistem informasi karena terlibatnya pengguna pada semua lini secara langsung. Pilihan masing-masing perusahaan bergantung pada kebutuhan dan kondisi yang ada di lapangan. Bisa juga karena alasan meminimalisir resiko tapi memerlukan banyak biaya atau sebaliknya.

Pertamina merupakan perusahaan milik negara yang bergerak di bidang energi meliputi minyak, gas serta energi baru dan terbarukan. Pertamina menjalankan kegiatan bisnisnya berdasarkan prinsip-prinsip tata kelola korporasi yang baik sehingga dapat berdaya saing yang tinggi di dalam era globalisasi. PT Pertamina Dengan pengalaman lebih dari 55 tahun, Pertamina semakin percaya diri untuk berkomitmen menjalankan kegiatan bisnisnya secara profesional dan penguasaan teknis yang tinggi mulai dari kegiatan hulu sampai hilir.Berorientasi pada kepentingan pelanggan juga merupakan suatu hal yang menjadi komitmen Pertamina,agar dapat berperan dalam memberikan nilai tambah bagi kemajuan dan kesejahteraan bangsa Indonesia.

Sejak didirikan pada 10 Desember 1957, Pertamina menyelenggarakan usaha minyak dan gas bumi di sektor hulu hingga hilir. Pada saat itu penyelenggaraan negara mulai berjalan normal seusai perang mempertahankan kemerdekaan, Pemerintah Republik Indonesia mulai menginventarisasi sumber-sumber pendapatan negara, di antaranya dari minyak dan gas. Namun saat itu, pengelolaan ladang-ladang minyak peninggalan Belanda terlihat tidak terkendali dan penuh dengan sengketa.

Pada tahun 1960, PT PERMINA direstrukturisasi menjadi PN PERMINA sebagai tindak lanjut dari kebijakan Pemerintah, bahwa pihak yang berhak melakukan eksplorasi minyak dan gas di Indonesia adalah negara. Melalui satu Peraturan Pemerintah yang dikeluarkan Presiden pada 20 Agustus 1968, PN PERMINA yang bergerak di bidang produksi digabung dengan PN PERTAMIN yang bergerak di bidang pemasaran guna menyatukan tenaga, modal dan sumber daya yang kala itu sangat terbatas. Perusahaan gabungan tersebut dinamakan PN Pertambangan Minyak dan Gas Bumi Nasional (Pertamina).Seiring dengan waktu, menghadapi dinamika perubahan di industri minyak dan gas nasional maupun global, Pemerintah menerapkan Undang-Undang No. 22/2001. Paska penerapan tersebut, Pertamina memiliki kedudukan yang sama dengan perusahaan minyak lainnya.

Pada 17 September 2003 Pertamina berubah bentuk menjadi PT Pertamina (Persero) berdasarkan PP No. 31/2003. Undang-Undang tersebut antara lain juga mengharuskan pemisahan antara kegiatan usaha migas di sisi hilir dan hulu. Bisnis sektor hulu Pertamina yang dilaksanakan di beberapa wilayah di Indonesia dan luar negeri meliputi kegiatan di bidang-bidang eksplorasi, produksi, serta transmisi minyak dan gas. Untuk mendukung kegiatan eksplorasi dan produksi tersebut, Pertamina juga menekuni bisnis jasa teknologi dan pengeboran, serta aktivitas lainnya yang terdiri atas pengembangan energi panas bumi dan Coal Bed Methane (CBM).

Dalam pengusahaan migas baik di dalam dan luar negeri, Pertamina beroperasi baik secara independen maupun melalui beberapa pola kerja sama dengan mitra kerja yaitu Kerja Sama Operasi (KSO), Joint Operation Body (JOB), Technical Assistance Contract(TAC), Indonesia Participating/Pertamina Participating Interest (IP/PPI), dan Badan Operasi Bersama (BOB).

Aktivitas eksplorasi dan produksi panas bumi oleh Pertamina sepenuhnya dilakukan di dalam negeri dan ditujukan untuk mendukung program pemerintah menyediakan 10.000 Mega Watt (MW) listrik tahap kedua. Di samping itu Pertamina mengembangkan CBM atau juga dikenal dengan gas metana batubara (GMB) dalam rangka mendukung program diversifikasi sumber energi serta peningkatan pasokan gas nasional pemerintah. Potensi cadangan gas metana Indonesia yang besar dikelola secara serius yang dimana saat ini Pertamina telah memiliki 6 Production Sharing Contract (PSC)-CBM.

Sektor hilir Pertamina meliputi kegiatan pengolahan minyak mentah, pemasaran dan niaga produk hasil minyak, gas dan petrokimia, dan bisnis perkapalan terkait untuk pendistribusian produk Perusahaan. Kegiatan pengolahan terdiri dari: RU II (Dumai), RU III (Plaju), RU IV (Cilacap), RU V (Balikpapan), RU VI (Balongan) dan RU VII (Sorong).

Selanjutnya, Pertamina juga mengoperasikan Unit Kilang LNG Arun (Aceh) dan Unit Kilang LNG Bontang (Kalimantan Timur). Sedangkan produk yang dihasilkan meliputi bahan bakar minyak (BBM) seperti premium, minyak tanah, minyak solar, minyak diesel, minyak bakar dan Non BBM seperti pelumas, aspal, Liquefied Petroleum Gas (LPG), Musicool, serta Liquefied Natural Gas(LNG), Paraxylene, Propylene, Polytam, PTA dan produk lainnya.

Dalam perusahaan proses penjualan merupakan proses yang sangat penting bagi perusahaan dalam meningkatkan pendapatan perusahaan. Oleh karena itu, diperlukan informasi yang dapat mendukung pengambilan keputusan bagi manajemen. Penerapan komputer dan sebuah sistem informasi penjualan menjadi suatu solusi karena dapat mendukung kinerja dalam bagian-bagian yang berhubungan dengan penjualan serta mendukung pengambilan 
keputusan bagi pihak manajerial untuk mencapai tujuan perusahaan. Sistem informasi penjualan berbasis komputer dalam penyajian informasi penjualan yang diperlukan dapat langsung disajikan baik pada layout layar monitor maupun media cetak. Sistem informasi penjualan berbasis komputer dapat mengolah data lebih cepat dan pelayanan yang diberikan dapat lebih baik melalui perangkat otomatisasi yang tersedia, selain itu kebutuhan akan informasi penjualan dapat disajikan secara cepat dan tepat waktu dengan adanya penyimpanan data secara elektronik yang mudah untuk di akses oleh pengguna sistem. Sistem informasi penjualan yang dijalankan dengan baik dalam suatu perusahaan maka akan sangat membantu dalam mendukung aktivitas penjualan dalam perusahaan. Penelitian ini bermaksud untuk menjelaskan bagaimana implementasi sistem informasi pada PT Pertamina.

\section{KERANGKA TEORITIS}

Sistem informasi adalah suatu sistem di dalam suatu organisasi yang mempertemukan kebutuhan pengolahan transaksi harian, mendukung operasi, bersifat manajerial dan kegiatan strategi dari suatu organisasi dan menyediakan pihak luar tertentu dengan laporan-laporan yang diperlukan. Berdasarkan definisi yang dijelaskan, penulis dapat menarik kesimpulan bahwa sistem informasi adalah kumpulan dari sistem yang terdiri dari kumpulan data yang saling berkaitan yang selanjutnya diproses untuk tujuan menyediakan informasi kepada pengguna untuk menunjang proses operasi.

Komponen sistem informasi terdiri dari beberapa blok bangunan [4] , yaitu: 1) Blok masukan yang merupakan input dari data, 2) Blok model merupakan bentuk model yang dibangun dalam sistem informasi, 3) Blok keluaran merupakan output informasi yang dihasilkan, 4) Blok teknologi merupakan penerapan teknologi yang dibuat, 5) Blok basis data merupakan tempat penyimpanan data dan, 6) Blok kendali merupakan bentuk pengendalian dari sistem informasi yang dibangun.

\subsection{Definisi Sistem Informasi Manajemen}

Menurut [5] sistem informasi manajemen adalah suatu sistem berbasis komputer yang menyediakan informasi bagi beberapa pemakai dengan kebutuhan serupa. Menurut [6] manajemen sistem informasi adalah proses pengelolaan teknologi informasi yang semakin kompleks dan penting mencakup beberapa dampak peran dari manajemen teknologi informasi yaitu tata kelola teknologi informasi (memutuskan siapa yang membuat keputusan TI), peran dari sistem informasi (mengalihkan fokus dari aplikasi pengiriman menjadi integrasi sistem dan pengembangan infrastruktur), serta persaingan yang terus menerus antara outsourcing dan insourcing menjadi cara untuk organisasi bertahan hidup. Peneliti menarik kesimpulan bahwa sistem informasi manajemen merupakan sebuah sistem berbasis komputer yang dikelola oleh pengguna dan menyediakan informasi untuk para pengguna sesuai kebutuhan. Output informasi yang dihasilkan akan digunakan oleh para manajer dan non-manajer untuk membuat keputusan. Keputusan tersebut diharapkan dapat memecahkan permasalahan di organisasi.

Tentunya untuk menjalankan SIM membutuhkan berbagai proses, inilah proses SIM dan aktivitas-aktivitasnya meliputi:

1. Perencanaan, Merupakan rumusan mengenai metode kegiatan secara rinci, untuk mencapai tujuan atau target akhir dari suatu organisasi. Jadi perencanaan merupakan langkah-langkah yang rinci untuk mencapai suatu tujuan organisasi.

2. Pengendalian, Jika perencanaan telah dibuat dan dilaksanakan atau di terapkan oleh anggota-anggota suatu organisasi, maka manajer harus mengawasi pelaksanaan dari perencanaan tersebut supaya dapat berjalan dengan baik dan tidak menyimpang dari jalur yang sudah ditetapkan.

3. Pengambilan keputusan Merupakan pemilihan keputusan diantara berbagai macam alternatif yang ada, proses ini merupakan hasil dari perencanaan dan pengendalian. Jadi manajer harus memilih diantara berbagai macam. keputusan yang ada supaya tujuan perusahaan atau organisasi dapat tercapai.

Dalam sistem informasi manajemen memiliki karakteristik informasi yang dibuat. Adapun karakeristik Sistem Informasi Manajemen diantaranya:

1. Meningkatkan efektifitas dan efesinsi dengan mengurangi pengeluaran biaya.

2. Beroperasinya pada tugas yang terstruktur yaitu seperti pada prosedur perencanaan, pengawasan dan pengambilan keputusan.

3. Menghasilkan Output misalnya berupa laporan yang berguna bagi manajemen untuk pengambilan suatu keputusan (keputusan yang diambli hasil dari pertimbangan dan analisis laporan).

Fungsi atau Manfaat SIM Secara Umum, Dapat disimpulkan dari penjelasan diatas tadi beberapa fungsi/manfaat SIM diantaranya:

1. Untuk memudahkan manajemen dalam melakukan perencanaan, pengawasan dan pengambilan keputusan.

2. Untuk meningkatkan efesiensi dalam mengakses data atau informasi supaya lebih cepat dan akurat.

3. Untuk meningkatkan kualitas dari sumber daya manusia dan sumber daya lainnya yang dapat mendukung organisasi atau perusahaan.

\subsection{Manfaat Sistem Informasi Manajemen Bagi Perusahaan}

Saat ini, sistem informasi sudah menjadi hal yang umum bagi perusahaan dan banyak orang. Sudah banyak perusahaan yang menggunakan sistem informasi untuk mempermudah dan mempercepat pekerjaan. Sistem informasi juga bisa meminimalisasi biaya-biaya, terutama yang terkait dengan pencatatan dan perekaman data. Namun, tidak sedikit pula yang menggunakan sistem informasi tanpa memerhatikan faktor biaya dan cara penggunaannya. Padahal, 
jika ditinjau dari pengaruhnya terhadap bisnis yang dijalankan, penggunaan sistem informasi yang tepat tidak hanya dapat mengurangi pengeluaran perusahaan, tetapi juga dapat meningkatkan pendapatan perusahaan. Berikut pengaruh lain dari penggunaan sistem informasi bagi perusahaan Anda:

1. Meningkatkan efektivitas alur kerja perusahaan

Salah satu manfaat penggunaan sistem informasi adalah membuat alur kerja perusahaan menjadi lebih efektif. Esensi dari bisnis sebenarnya bukan terletak pada jumlah, melainkan kecepatan. Mampu menghasilkan produk banyak, tetapi dalam kurun waktu yang lama tentu bukanlah suatu prestasi yang patut dibanggakan. Banyak perusahaan yang tidak mampu mencapai level kecepatan tertinggi dalam produksi bukan karena belum menggunakan sistem informasi, melainkan karena belum menggunakan sistem informasi yang tepat. Sistem informasi yang tepat mampu menyediakan laporan yang lengkap mengenai produktivitas perusahaan beserta dengan alur-alur kerjanya. Berdasarkan laporan tersebut, perusahaan bisa membuat analisis mengenai efektif tidaknya alur kerja yang selama ini telah dijalankan. Jika tidak efektif, tentu saja harus ada perubahan alur kerja: bisa melalui penghapusan beberapa pekerjaan yang tidak efektif atau mengubah susunan alur kerja.

2. Meningkatkan produktivitas sumber daya manusia

Penggunaan sistem informasi yang tepat bisa membuat perusahaan mampu mengevaluasi sumber daya manusia yang dimiliki, terutama kaitannya dengan penempatan kerja dan kapasitas kerja. Apakah selama ini pegawai sudah ditempatkan sesuai dengan bidang yang dikuasai? Apakah selama ini pegawai bekerja sesuai dengan kapasitas yang dimiliki? Jika belum, barangkali itu bisa menjadi salah satu faktor penyebab perusahaan Anda belum berkembang juga. Salah satu ciri perusahaan yang baik adalah mampu menempatkan pegawainya sesuai dengan bidang yang dimiliki dan membuat para pegawainya bekerja sesuai dengan kapasitas yang dimiliki, bukan kapasitas yang diinginkan perusahaan. Pegawai yang bekerja sesuai bidang dan kapasitasnya akan mampu menghasilkan produktivitas kerja yang lebih tinggi. Dengan produktivitas kerja yang tinggi, tentu kecepatan produksi suatu perusahaan juga otomatis akan meningkat.

3. Meminimalisasi produk cacat

Sistem informasi yang baik mampu memberikan data yang akurat, bahkan pada saat proses pengerjaan suatu produk sekalipun. Hal itu tentu membuat pengerjaan suatu produk dapat dipantau dengan mudah sehingga bisa meminimalisasi cacatnya produk ketika sudah selesai diproduksi. Perihal mengetahui cacat produk saat pengerjaan tentu jauh lebih baik dibandingkan baru mengetahui cacat produk setelah proses produksi selesai. Dengan demikian, biaya proses produksi pun dapat lebih aman lagi.

Adapun beberapa manfaat yang didapatkan dari SIM untuk perusahaan, diantaranya:

1. Adanya ketersediaan kualitas dan keterampilan dalam memanfaatkan sistem informasi.

2. Meningkatkan aksesbilitas informasi secara tepat waktu dan secara akurat untuk para penggunanya, tanpa diperlukan perantara.

3. Dapat berguna untuk mengelola berbagai transaksi, mengurangi biaya dan menghasilkan informasi baru yang dapat menciptakan keuntungan.

4. Dapat mengembangkan proses perencanaan yang telah dibuat supaya menjadi lebih efektif.

5. Dapat mengidentifikasi berbagai macam kebutuhan keterampilan yang mendukung sistem informasi.

6. Mengantisipasi dan memahami berbagai macam konsekuensi ekonomis dari suatu sistem informasi dan teknologi yang baru.

7. Memperbaiki produktivitas dalam aplikasi pemeliharaan maupun pengembangan sistem informasi.

8. Mendukung untuk pengambilan suatu keputusan manajemen.

\subsection{Contoh Sistem Informasi Manajemen}

Beberapa contoh kongkrit penerapan sistem informasi manajemen adalah sebagai berikut: 1) Enterprise Resource Planning (ERP), Sistem ERP ini biasanya digunakan oleh sejumlah perusahaan besar dalam mengelola manajemen dan melakukan pengawasan yang saling terintegrasi terhadap unit bidang kerja Keuangan, Accounting, Sumber Daya Manusia, Pemasaran, Operasional, dan Pengelolaan Persediaan. 2) Supply Chain Management (SCM), Sistem SCM ini sangaat bermanfaat bagi pihak manajemen dimana data data yang disajikan terintegrasi mengenai manajemen suplai bahan baku, mulai dari pemasok, produsen, pengecer hingga konsumen akhir. 3) Transaction Processing System (TPS), TPS ini berguna untuk proses data dalam jumlah yang besar dengan transaksi bisnis yang rutin. Program ini biasa diaplikasikan untuk manajemen gaji dan inventaris. Contohnya adalah aplikasi yang digunakan untuk Bantuan Keuangan Desa Pemprov Jawa Timur. 4) Office Automation System (OAS), Sistem aplikasi ini berguna untuk melancarkan komunikasi antar departemen dalam suatu perusahaan dengan cara mengintegrasikan server-server komputer pada setiap user di perusahaan. Contohnya adalah email. 5) Knowledge Work System (KWS), Sistem informasi KWS ini mengintegrasikan satu pengetahuan baru ke dalam organisasi. Dengan ini, diharapkan para tenaga ahli dapat menerapkannya dalam pekerjaan mereka. 6) Informatic Management System (IMS), IMS berfungsi untuk mendukung spektrum tugas-tugas dalam organisasi, yang juga dapat digunakan untuk membantu menganalisa pembuatan keputusan. Sistem ini juga dapat menyatukan beberapa fungsi informasi dengan program komputerisasi, seperti e-procurement. 7) Decision Support System (DSS), Sistem ini membantu para manajer dalam mengambil keputusan dengan cara mengamati lingkungan dalam perusahaan. Contohnya, Link Elektronik di sekolah Tunas Bangsa, yang mengamati jumlah pendapatan atau pendaftaran siswa baru setiap tahun. 8) Expert System (ES) dan Artificial Intelligent (A.I.), Sistem ini pada dasarnya menggunakan kecerdasan buatan untuk menganalisa pemecahan 
masalah dengan menggunakan pengetahuan tenaga ahli yang telah diprogram ke dalamnya. Contohnya, sistem jadwal mekanik. 9) Group Decision Support System (GDSS) dan Computer-Support Collaborative Work System(CSCWS), Serupa dengan DSS, tetapi GDSS mencari solusi lewat pengumpulan pengetahuan dalam satu kelompok, bukan per individu. Biasanya berbentuk kuesioner, konsultasi, dan skenario. Contohnya adalah e-government. 10) Executive Support System (ESS), Sistem ini membantu manajer dalam berinteraksi dengan lingkungan perusahaan dengan berpegang pada grafik dan pendukung komunikasi lainnya.

\section{METODELOGI PENELITIAN}

Yang menjadi subjek dalam penelitian adalah PT Pertamina, adapun analisis data menggungakan analisis kualitatif dengan pendekatan systematic review. Pendekatan systematic review digunakan untuk mensistesis atau merangkum hasil-hasil penelitian yang bersifat deksriptif kualitatif. Dalam penelitian ini pengambilan data adalah melaui searching di internet. Adapun langkah-langkah systematic review kualitatif mencangkup langkah-langkah sebagai berikut [7] meliputi:

1. Memformulasikan pertanyaan penelitian (formulating the review question)

2. Melakukan pencarian literature systematic review (conducting a systematic literature search)

3. Melakukan skrining dan seleksi artikel penelitian yang cocok (screening and selecting approptiate research articles)

4. Melakukan analisis dan sistesis temuan-temuan kuantitaif (analyzing and sysnthesizing quantitative findings)

5. Memberlakukan kendali mutu (maintaining quality control)

6. Menyususn laporan akhir (presenting findings)

\section{HASIL DAN PEMBAHASAN}

Penerapan Sistem Informasi Manajemen yang sudah diterapkan pada PT. Pertamina. Perancangan, penerapan dan pengoperasian sistem informasi manajemen adalah mahal dan sulit. Upaya ini dan biaya yang diperlukan harus ditimbang-timbang. Ada beberapa faktor yang membuat SIM menjadi semakin diperlukan, antara lain bahwa manajer harus berhadapan dengan lingkungan bisnis yang semakin rumit. Salah satu alasan dari kerumitan ini adalah semakin meningkatnya dengan munculnya peraturan dari pemerintah.

Lingkungan bisnis bukan hanya rumit tetapi juga dinamis. Oleh sebab itu manajer harus membuat keputusan dengan cepat terutama dengan munculnya masalah manajemen dengan munculnya pemecahan yang memadai. Sistem informasi manajemen SIM bukan sistem informasi keseluruhan, karena tidak semua informasi di dalam organisasi dapat dimasukkan secara lengkap ke dalam sebuah sistem yang otomatis. Aspek utama dari sistem informasi akan selalu ada di luar sistem komputer.

Mengingat begitu pentingnya peranan dari manajeman sistem informasi, maka sudah sewajarnya semua kegiatan perusahaan menerapkan manajemen sistem informasi demi efisiensi dan efektifitas kinerja perusahaan dalam mencapai target perusahaannya. Kita bisa membandingkan, tingkat efektifitas kinerja perusahaan antara 2 perusahaan antara yang menggunakan manajemen sistem informasi dengan perusahaan yang masih menganut sistem kontemporer / konservatif. Makalah ini menyajikan studi kasus tentang penerapan manajeman sistem informasi pada PT Pertamina yang penulis himpun dari berbagai sumber.

4.1 Sistem Informasi yang digunakan PT. Pertamina

PT. Pertamina menggunakan berbagai sistem informasi untuk menunjang operasi bisnis. Salah satu sistem

informasi yang digunakan adalah dalam procurement sysytem. Procurement system adalah proses pemilihan

sumber, pemesanan, dan perolehan barang dan jasa. Barang dan jasa ini biasanya diperoleh dari sumber luar.

Dalam menjalankan procurement system ini, PT. Pertamina menggunakan bantuan program MySAP dan

eProc dalam memilih vendor terbaik. Tahap-tahap dalam procurement system ini adalah sebagai berikut:

1. Penentuan kebutuhan

2. Penentuan sumber pemenuhan kebutuhan

3. Pemilihan vendor

4. Pemrosesan Purchasing Order (PO)

5. Pemantauan Purchasing Order (PO)

6. Penerimaan produk

7. Verifikasi invoice

8. Proses pembayaran

4.2 Gambaran Penerapan Sistem Informasi

1. Sistem Informasi SPBU PT. Pertamina

Sistem Informasi SPBU suatu sistem software yang akan membantu proses operasional dengan menerapkan tertib administrasi pada Pompa SPBU yang ketat Pencatatan dari data customer,stok minyak, deposit di pertamina, Kupon Customer dan lain lain. Produk ini custom dan cocok untuk pengelola SPBU . Dilengkapi dengan sistem pelaporan yang sistematis dan akurat. SistemInformasi SPBU ini dibuat dengan sistem multi user yang memungkinkan pengaksesan sistem informasi oleh beberapa user yang berbeda dalam suatu waktu. Sistem ini dirancang dengan sistem keamanan yang handal yang mana setiap level user diset dalam ruang lingkup pekerjaanyang berbeda berdasar urutan otorisasi. 
2. Sistem Informasi Manajemen Pemasaran PT. Pertamina

Pemasaran merupakan sebuah proses dalam memuaskan kebutuhan dan keinginan manusia. Jadi,segala kegiatan dalam hubungannya dalam pemuasan kebutuhan dan keinginan manusiamerupakan bagian dari konsep pemasaran.Pemasaran BBM Retail merupakan salah satu fungsi di Direktorat Pemasaran dan Niaga yangmenangani pemasaran BBM retail untuk sektor transportasi dan rumah tangga. Pertaminamelakukan pemasaran BBM Retail melalui lembaga penyalur Retail BBM/BBK yang saat initersebar diseluruh Indonesia, seperti SPBU (Statiun Pengisian BBM Untuk Umum), AgenMinyak Tanah (AMT), Agen Premium \& Minyak Solar (APMS), serta Premium Solar Packed Dealer (PSPD).

4.3 Identifikasi Sumberdaya Dalam Penerapan Sistem Informasi

1. Komponen sistem informasi

a. Sumberdaya Manusia

Sumberdaya manusia yang digunakan oleh PT. Pertamina untuk memakai dan menjalankan sistem informasi terdiri dari user dan spesialis. Users (unit procurement) adalah semua orang yang menggunakan sistem informasi tersebut. Sedangkan spesialis (teknisi dan supervisor) adalah orang-orang yang mempunyai keahlian dalam menggunakan sistem tersebut. Dalam setiap aktivitas sistem informasi, sumberdaya spesialis dan users terlibat.

b. Perangkat Keras (Hardware)

Perangkat keras yang digunakan dalam procurement system adalah diantaranya PC Work Stasion, Server, LAN, Printer.

c. Perangkat Lunak (Software) EProc

Perangkat lunak yang digunakan dalam procurement system adalah diantaranya MySAP, Web $P 2 P$,

\section{d. Sumber Data}

Sumber data dalam procurement system PT. Pertamina adalah sebagai berikut:

1. Purchase Requisition (PR)

Purchase requisition adalah pembelian berbagai kebutuhan, baik dari PT. Pertamina maupun pelanggan.

2. Vendor quotation

Vendor quotation adalah suatu tawaran dari vendor mengenai penyediaan material dan jasa seperti yang diminta dalam RFQ, juga berisikan persyaratan-persyaratan tertentu (termasuk harga).

3. Request for Quotation (RFQ)

RFQ adalah dokumen yang dibuat untuk tujuan meminta penawaran harga dari vendor untuk spesifik material/service.

4. Purchase Order (PO)

5. Produk Informasi

Produk informasi yang dihasilkan dari procurement system adalah data vendor quotation dalam SAP, maintain RFQ di dalam sistem MySAP untuk vendor pemenang, vendor terpilih untuk proses procurement, surat penolakan pada vendor yang tidak sesuai, referensi vendor di masa datang, dan pencetakan purchase order.

2. Aktivitas Sistem Informasi

a. Input

Mesin yang digunakan dalam proses input adalah PC Work Station, server, dan LAN, sedangkan program yang digunakan adalah $M y S A P$ dan $W e b$ P2P. Sumberdaya manusia yang terlibat dalam proses input terdiri atas spesialis (teknisi dan supervisor) dan user (unit procurement). Sumber data yang digunakan berasal dari purchase requisition dan vendor quotation. Produk informasi yang dihasilkan dari proses input adalah data vendor quotation berbagai vendor yang sudah masuk ke dalam SAP.

b. Proses

Mesin yang digunakan dalam tahap proses adalah PC Work Station, server, dan LAN, sedangkan program yang digunakan adalah $M y S A P$ dan eProc. Sumberdaya manusia yang terlibat dalam tahap proses terdiri atas spesialis (teknisi dan supervisor) dan user (unit procurement). Sumber data yang digunakan berasal dari vendor quotation dan request for quotation (RFQ). Produk informasi yang dihasilkan dari tahap ini adalah maintain RFQ di dalam sistem MySAP untuk vendor pemenang.

c. Output

Mesin yang digunakan dalam tahap output adalah PC Work Station, server, dan LAN, sedangkan program yang digunakan adalah $M y S A P$, Web P2P, dan eProc. Sumberdaya manusia yang terlibat dalam proses output terdiri atas spesialis (teknisi dan supervisor) dan user (unit procurement). Sumber data yang digunakan berasal dari vendor quotation dan request for quotation (RFQ). Produk informasi yang dihasilkan dari proses output adalah terpilihnya vendor yang memiliki penawaran terbaik dan surat penolakan pada vendor yang tidak sesuai.

d. Penyimpanan 
Mesin yang digunakan dalam tahap penyimpanan adalah PC Work Station, server, dan LAN, sedangkan program yang digunakan adalah MySAP, Web P2P, dan eProc. Sumberdaya manusia yang terlibat dalam proses penyimpanan terdiri atas spesialis (teknisi dan supervisor) dan user (unit procurement). Sumber data yang digunakan berasal dari vendor quotation. Produk informasi yang dihasilkan dari proses penyimpanan adalah referensi vendor di masa datang.

e. Pengendalian

Mesin yang digunakan dalam tahap pengendalian adalah PC Work Station, server, dan LAN, sedangkan program yang digunakan adalah MySAP, Web P2P, dan eProc. Sumberdaya manusia yang terlibat dalam proses pengendalian terdiri atas spesialis (teknisi dan supervisor) dan user (unit procurement). Sumber data yang digunakan berasal dari purchase order. Produk informasi yang dihasilkan dari proses pengendalian adalah release PO, pencetakan PO, dan pemberian PO kepada vendor.

3. Tipe Sistem Informasi

a. Operation Support System

1. Transaction processing system

TPS adalah sistem informasi yang terkomputerisasi yang dikembangkan untuk memproses data transaksi bisnis rutin. TPS yang dilakukan pada PT. Pertamina adalah berupa pencatatan transaksi penjualan kepada konsumen dan pembelian material (procurement system) serta pencatatan inventory. Berikut disajikan bagan procurement system di PT. Pertamina.

Procurement system ini dimulai dengan pemenuhan kebutuhan yang didasarkan pada permintaan dari pelanggan dan permintaan dari Pertamina sendiri. Setelah kebutuhan ditentukan, maka selanjutnya ditentukan sumber pemenuhan kebutuhan. Lalu, untuk mengidentifikasi vendor, maka dapat menggunakan sistem dan data dari pembelian sebelumnya. Setelah vendornya dipilih, maka dibuat Purchase Order. Purchase Order (PO) mengidentifikasikan vendor, dan mengkonfirmasikan produk dan jasa yang dipesan, jumlah yang dibutuhkan, dan harga yang disetujui. Setelah Purchase Order dibuat dan dikirim ke vendor, suplier mengantarkan produk tersebut ke Pertamina. Oleh karena itu, langkah berikutnya dalam proses procurement adalah memasukkan Goods Receipt. Goods Receipt dilakukan saat produk diterima dalam gudang Pertamina.Penerimaan produk dapat diposting ke dalam SAP menggunakan InventoryManagement. Untuk pembayaran pembelian material tersebut, sistem akan mencatatkan transaksi General Ledger.

2. Process Control System

PCS merupakan sistem yang membantu organisasi dalam hal evaluasi dan kontrol. Pada PT. Pertamina terutama dalam Procurement Process sistem ini digunakan untuk pemantauan order pembelian material. Purchase Order dapat diubah bahkan dibatalkan dalam tahap monitoring ini.

Selain itu, PCS juga digunakan untuk verifikasi invoice yang diterima pada procurement melalui komponen logistics invoice verification. Verifikasi berguna untuk memeriksa keakuratan invoice tersebut. Sistem melakukan tiga cara pencocokan akuntansi pada invoice, yaitu Purchase Order, Goods Receipt dan Invoice.

\section{Enterprise Collaboration System}

ECS adalah sistem informasi yang membantu organisasi dalam hal komunikasi. PT. Pertamina menggunakan sistem ini untuk bisa terhubung antar pihak internal perusahaan dan terhubung dengan pihak luar seperti dengan pemasok (vendor) dan pembeli termasuk dalam hal negosiasi.

b. Management Support System

1. Management information system

MIS adalah suatu aplikasi Sistem Informasi yang menyediakan laporan informasi terpadu bagi pihak manajemen. MIS yang dilakukan pada PT. Pertamina adalah berupa pelaporan informasi penting seperti neraca dan laporan laba rugi perusahaan. Dalam hal transaksi pembelian material, maka ada pelaporan mengenai kecocokan antara purchase order, goods receipt dan invoice.

2. Decision support system

DSS menekankan pada fungsi pendukung pembuat keputusan. DCS digunakan oleh PT. Pertamina pada Procurement Process dalam hal menyeleksi vendor untuk pembelian material dan menentukan jumlah barang yang dipesan.

3. Executive information system

PT. Pertamina menggunakan sistem informasi ini untuk membantu top management mengakses ringkasan dan grafik tertulis mengenai elemen kunci kinerja organisasi dan mengambil keputusan untuk meningkatkan kinerja perusahaan.

4. Identifikasi permasalahan Sistem Informasi Procurement PT. Pertamina

Kontrol secara terdistribusi di unit-unit di Pertamina telah memunculkan beragam isu fundamental ERP:

a. SDM, isu-isu fundamental pada sumber daya manusia:

a) Terbatasnya sumber daya yang terampil dan kompeten sehingga sulit memberikan solusi bagi unit dan pusat. 
b) Tidak semua user memahami SAP dengan baik.

c) User belum menggunakan sistem dengan tertib.

d) User terlibat dalam proses data sehingga kurang fokus pada bisnis inti.

e) Pelatihan belum dilakukan dengan optimal.

b. Proses dan Change Management, isu-isu fundamental pada proses dan change management antara lain:

a) Tidak adanya standardisasi proses

b) Perubahan yang dilakukan satu unit mengakibatkan masalah lebih rumit.

c) Tidak adanya kepatuhan terhadap proses.

d) SOP diinterpretasikan berbeda-beda tanpa kendali

c. Sistem, isu-isu fundamental pada sistem antara lain:

a) Lemahnya kontrol atas proses transaksi sampai tutup buku

b) Komitmen yang lemah karena kontrol tersebar

c) Tidak maksimalnya pemanfaatan fungsi-fungsi dan user ID SAP

d) Sulitnya kontrol terhadap user yang tidak tertib

Selain itu, desentralisasi juga telah menimbulkan deviasi proses yang signifikan dan tidak adanya standarisasi proses. Ketidakmampuan menerapkan standar menimbulkan adanya fleknilitas yang tinggi bagi user untuk melakukan deviasi dari berbagai SOP yang ada. Pada berbagai proses procurement, terdapat isuisu fundamental yang terjadi, yakni meliputi:

a. Proses purchase requisition (PR) memiliki isu PR tidak selalu dibuat sebagaimana ditetapkan dalam SOP.

b. Proses $R F Q / q u o t a t i o n$ memiliki isu antara lain penunjukkan langsung dan tidak menggunakan service master.

c. Proses penerbitan purchase order (PO) memiliki isu pembuatan PO tanpa PR.

d. Proses goods receipt memiliki isu tidak tepat waktu.

e. Proses invoice verification memiliki isu banyak ditemukan kesalahan pada invoice.

f. Proses accounts payable memiliki isu direct FI posting untuk item-item kecil dan sundry (tanpa PR/PO)

\section{KESIMPULAN}

Penerapan sistem informasi di PT. Pertamina membawa manfaat yang sangat baik sebagai penunjang keberhasilan perusahaan dalam rangka efisiensi dan efektifitas kinerja perusahaan. Memberi informasi yang lebih akurat sehingga perusahaan PT. Pertamina bisa memperkirakan dan membidik target pasar agar tepat dalam prencanaannya. Memberikan nilai yang inovatif dan kreatif dalam meenciptakan produk baru dan tentu saja akan menumbuhkan minat konsumen dalam membeli produk-produk terbaru PT. Pertamina. Sistem informasi pada PT. Pertamina membuat perusahaan tersebut dapat bersaing dengan perusahaan dari luar sekalipun dan development terhadap sistem di PT Pertamina sudah sangat baik dan up to date.

Berdasarkan kesimpulan diatas, maka saran-saran yang dapat diberikan sebagai tindak lanjut atas pelaksanaan audit terhadap sistem informasi sumber daya manusia sebagai berikut:

1. Peningkatan kompetensi karyawan melalui pelatihan dan workshop dalam bidang sistem informasi dan pengontrolannya

2. Menyediakan fasilitas pendukung untuk melindungi perusahaan maupun asset perusahaan berupa arsip atau data-data seperti menyediakan system dry-pipe automatic sprinkler.

3. Mengembangkan sistem SDM dalam bidang teknologi informasi

4. Untuk penelitian selanjutnya dapat meneliti tentang implementasi pada perusahaan dengan asset besar lainnya atau meneliti pengaruh implementasi teknologi informasi terhadap kinerja perusahaan.

\section{REFERENSI}

[1] A. Ahmad, "Perkembangan Teknologi Komunikasi Dan Informasi," Dakwah Tabligh, 2012.

[2] J. Simarmata, Perancangan Basis Data. 2008.

[3] H. Al Fatta, "Analisis dan Perancangan Sistem Informasi untuk Keunggulan Bersaing Perusahaan dan Organisasi Modern,” Yogyakarta: Andi Offset. 2007.

[4] D. Setyawan, "Analisis Implementasi Pemanfaatan Sistem Informasi Manajemen Rumah Sakit (Simrs) Pada Rsud Kardinah Tegal,” Indones. J. Comput. Inf. Technol., 2016.

[5] G. Mcleod, "Learning Theory and Instructional Design," Learn. Matters, 2001.

[6] B. McNurlin, "Will Users of ERP Stay Satisfied?," MIT Sloan Manag. Rev., 2001.

[7] K. S. Khan, R. Kunz, J. Kleijnen, and G. Antes, "Five steps to conducting a systematic review," Journal of the Royal Society of Medicine. 2003.

(https://prezi.com/sge1kpt7sh-o/sistem-informasi-akuntansi-pt-pln/) Di akses tanggal 23 maret 2020 .

(http://www.bumn.go.id/pertamina/halaman/47) Di akses tanggal 24 maret 2020

(http://www.pertamina.com/company-profile/sejarah-pertamina/) Di akses tanggal 24 maret 2020 
(http://bdkpadang.kemenag.go.id/index.php?option=com_content\&view=article\&id=508:peranan-sisteminformasi-manajemen-sim-dalam-organisasi\&catid=41:top-headlines) Di akses tanggal 24 maret 2020 